\title{
ANALISIS KESESUAIAN PENULISAN RESEP PASIEN JANTUNG BERDASARKAN FORMULARIUM NASIONAL DAN $e$-CATALOGUE DI RUMAH SAKIT KARAWANG Maya Arfania*, Ernawati
}

Program Studi Farmasi Fakultas Farmasi Universitas Buana Perjuangan Karawang.

*Penulis korespondensi : maya.arfania@ubpkarawang.ac.id

\begin{abstract}
ABSTRAK
Penyakit kardiovaskular merupakan penyakit gangguan jantung dan pembuluh darah yang sering terjadi di kalangan masyarakat, salah satunya adalah penyakit jantung koroner (PJK). Pada era JKN, resep yang diberikan terhadap pasien harus mengacu pada Formularium Nasional (Formularium Nasional) dan e-Catalogue. Tujuan dilakukan penelitian ini adalah untuk menghitung persentase kesesuaian penulisan resep obat pada pasien dengan PJK berdasarkan Formularium Nasional dan e-Catalogue serta biaya rata-rata obat akibat penggunaan obat non Formularium Nasional dan non $e$-Catalogue. Penelitian ini merupakan penelitian deskriptif. Sampel dalam penelitian ini adalah 202 lembar resep dengan teknik pengambilan sampel secara Purposive Sampling. Hasil penelitian menunjukkan persentase kesesuaian penulisan resep obat baru mencapai 71,32 \% dan sebanyak 28,68 \% adalah resep yang ditulis dengan obat non Formularium Nasional dan non e-Catalogue. Sedangkan biaya rata-rata obat yang dikeluarkan per pasien karena peresepan obat non Formularium Nasional dan non e-Catalogue yaitu sebesar $\operatorname{Rp} 217.173,26,-$.
\end{abstract}

Kata Kunci: Penyakit Jantung Koroner, Persentase kesesuaian penulisan resep obat, Formularium Nasional, e-Catalogue.

\section{PRESCRIBING ANALYSIS FOR HEART PATIENT BASED ON NATIONAL FORMULARIUM AND E-CATALOGUE IN KARAWANG HOSPITAL}

\begin{abstract}
Cardiovaskular disease is a heart and blood vessels disorders that frequently occurs, one of them is Coronary Heart Disease (CAD). In the era of JKN, prescribing should be referred to the National Formulary (Formularium Nasional) and e-catalogue. The aim of this study were to determine the suitability CAD patient's prescribing with Formularium Nasional and
\end{abstract}


e-catalogue. This research is a observational study. The sample of this study was 202 prescribing with a purposive random sampling technique. The result showed that the prescribing suitability was $71.32 \%$ and as much as $28.68 \%$ was a prescribing written by a non Formularium Nasional and e-catalogue. The average cost of non Formularium Nasional and non e-catalogue prescribing was $R p$ 217.173,26,-

Keywords: Coronary Heart Disease, Percentage suitability prescribing, National Formulary, Ecatalogue.

\section{PENDAHULUAN}

Penyakit kardiovaskular merupakan penyakit gangguan pada jantung dan pembuluh darah yang sangat sering terjadi di kalangan masyarakat (Taroreh, 2017). Berdasarkan laporan statistik di Inggris tahun 2014, Penyakit kardiovaskular adalah penyebab utama kematian di seluruh dunia setelah penyakit kanker dimana hampir 30\% dari seluruh kematian disebabkan oleh penyakit kardiovaskular. Penyebab utama kematian penyakit kardiovaskular adalah Penyakit Jantung Koroner (PJK) dan stroke (Bhatnagar, 2016). Prevalensi PJK di Indonesia tahun 2013 pada penderita dengan usia diatas 15 tahun sekitar 883.447 orang, sedangkan estimasi jumlah penderita PJK yang terbanyak terdapat di Provinsi Jawa Barat yaitu sekitar 160.812 orang (Infodatin, 2014). Total kunjungan pasien rawat inap di salah satu rumah sakit di Depok selama tahun 2015 tercatat bahwa total kunjungan pasien PJK yang di rawat inap sebanyak 2.949 kunjungan sedangkan pasien rawat jalan sebanyak 45.775 kunjungan (Aurelia, 2017).

Tingginya angka penyakit kardiovaskular khususnya PJK menyebabkan biaya pengobatan untuk penyakit tersebut sangat tinggi, terlebih jika ada penyakit komplikasi maka biaya yang dikeluarkan untuk penanganan dan pengobatan pasien akan semakin tinggi pula. Pembiayaan penyakit katastrofik menurut data dari BPJS tahun 2016 menghabiskan biaya hampir 14,6 triliun rupiah dengan biaya yang paling besar yaitu penyakit jantung sebesar 7,4 Triliun Rupiah (50,7\%) (Kemenkes RI, 2017). Pada era Jaminan Kesehatan Nasional (JKN) resep yang diberikan terhadap pasien harus mengacu pada Formularium Nasional, karena resep yang tidak sesuai dengan Formularium Nasional akan berpengaruh terhadap mutu pelayanan serta profit rumah sakit (Pratiwi, 2017). Ketidaksesuaian peresepan obat terhadap Formularium Nasional juga dapat berakibat pada biaya obat yang dipergunakan tidak efisien (Hanifa, 2017). Penelitian yang dilakukan oleh khairunnisa (2016) di salah satu Rumah Sakit Umum Swasta di Bandung menunjukkan berdasarkan tingkat kesesuaian peresepan obat dengan Formularium Nasional, penggunaan obat yang 
sesuai dengan Formularium Nasional baru mencapai 71,26\%. Artinya sebesar $28,74 \%$ penggunaan obat lainnya merupakan obat non Formularium Nasional.

Tujuan penelitian ini adalah untuk melihat berapa besar persentase penulisan resep obat kardiovaskular pada penyakit jantung koroner berdasarkan Formularium Nasional dan $e$-Catalogue serta berapa besar rata-rata biaya obat non Formularium Nasional dan non $e$ Catalogue.

\section{BAHAN DAN METODE}

\section{Alat dan Bahan}

Alat yang digunakan dalam penelitian ini adalah lembar kerja pengumpul data penelitian, e-Catalogue 2018, sistem komputerisasi Rumah Sakit (Medinfras), dan surat ijin penelitian dari Rumah Sakit Nomor 069/Dirut-Ex/RSM/I/2019. Bahan dan sumber data penelitian diperoleh dari rekam medis dan lembar resep pasien penyakit jantung koroner yang menjalani rawat jalan di Rumah Sakit Swasta Karawang.

\section{Penetuan Sampel dan Teknik Sampling}

Populasi dalam penelitian ini adalah seluruh lembar resep dengan diagnosa PJK periode Januari - Juni 2018 di Poliklinik Jantung Rumah Sakit Swasta Karawang. Penelitian ini merupakan penelitian observasional dimana data diambil secara retrospektif. Teknik pengambilan sampel dilakukan secara purposive sampling. Penentuan jumlah sampel menggunakan rumus Slovin (Hanifa, 2017):

$$
n=\frac{\mathrm{N}}{1+\mathrm{N} e^{2}}=\frac{406}{1+(406)(0,05)^{2}}-202
$$

Keterangan:

$\mathrm{n}$ : ukuran sampel

$\mathrm{N}$ : ukuran populasi (406 resep)

e : tingkat kesalahan $(5 \%)$

Sehingga jumlah sampel yang digunakan dalam penelitian ini adalah sebesar 202 lembar resep.

\section{Perhitungan Data}

Data diambil dari lembar resep pasien BPJS kesehatan yang mendaftar ke Poliklinik jantung Rumah Sakit swasta Karawang periode Januari - Juni 2018. Data yang diperoleh kemudian diolah dan dianalisis. Kesesuaian penulisan resep diukur dengan menghitung 
persentase antara jumlah item resep obat yang sesuai dengan formularium dan e-Catalogue dan jumlah semua item resep obat yang ditulis dalam resep.

Kesesuaian penulisan resep obat $=\frac{\text { jumlah resep obat sesuai formularium }}{\text { jumlah resep obat yang ditulis }} \times 100 \%$

Hasil analisis data disajikan dalam bentuk persentase disertai dengan penjelasan secara deskriptif yang terdiri dari persentase kesesuaian penulisan resep obat, jenis obat (generik dan nama dagang) dan biaya rata-rata obat.

\section{HASIL DAN PEMBAHASAN}

\section{Persentase Kesesuaian Penulisan Resep Obat}

Penelitian yang dilakukan di poliklinik jantung Rumah Sakit Swasta Karawang menunjukkan bahwa pada periode bulan Januari sampai Juni 2018 terdapat sejumlah 202 lembar resep dengan jumlah R/ untuk obat kardiovaskular sebanyak 914 kali. Dari 914 R/ obat kardiovaskular, sebanyak $650 \mathrm{R} /$ sesuai dengan Formularium Nasional dan $e$ Catalogue. Persentase kesesuaian resep dapat dilihat pada Tabel 1.

Tabel 1. Persentase kesesuaian penulisan resep obat kardiovaskular berdasarkan kesesuaian dengan Formularium Nasional 2017 dan e-Catalogue 2018 periode Januari - Juni 2018.

\begin{tabular}{ccccccc}
\hline No. & Bulan & $\begin{array}{c}\text { Jumlah } \\
\text { R/ }\end{array}$ & $\begin{array}{c}\text { R/ Sesuai } \\
\text { Formularium } \\
\text { Nasional \& } \\
\text { e-Catalogue }\end{array}$ & $\%$ & $\begin{array}{c}\text { R/ Tidak Sesuai } \\
\text { Formularium } \\
\text { Nasional \& } \\
\text { e-Catalogue }\end{array}$ & \% \\
\hline 1 & Januari & 29 & 21 & 72,41 & 8 & 27,58 \\
2 & Februari & 81 & 64 & 79,01 & 17 & 20,99 \\
3 & Maret & 158 & 114 & 72,15 & 44 & 27,85 \\
4 & April & 285 & 205 & 71,93 & 80 & 28,07 \\
5 & Mei & 240 & 173 & 72,08 & 67 & 27,92 \\
6 & Juni & 121 & 73 & 60,33 & 48 & 39,67 \\
Jumlah & 914 & 650 & 430,5 & 263 & 169,5 \\
\multicolumn{2}{c}{ Rata-Rata } & 152,33 & 108 & 71,32 & 44 & 28,68 \\
\hline
\end{tabular}

Dilihat dari Tabel 1 tampak bahwa peresepan obat yang telah sesuai dengan Formularium Nasional dan e-Catalogue baru mencapai 71,32 \%, sedangkan sebanyak 28,68\% merupakan resep yang berisi obat-obat kardiovaskular diluar Formularium Nasional dan e-Catalogue. Hal ini menunjukkan bahwa peresepan obat kardiovaskular pasien BPJS belum 100\% mengacu pada Formularium Nasional dan e-Catalogue. Menurut Dianingtyas \& Prasetyo (2015) yang menjadi penyebab ketidaksesuaian penulisan resep dengan 
Formularium Nasional dan e-Catalogue adalah karena dokter penulis resep belum terbiasa untuk menuliskan resep sesuai dengan Formularium Nasional dan e-Catalogue atau bisa juga karena kurangnya obat yang dicantumkan dalam Formularium Nasional dan $e$ Catalogue. Selain itu, faktor-faktor lain yang menjadi penyebab penulisan resep tidak sesuai dengan Formularium Nasional dan e-Catalogue yaitu faktor medis yang berkaitan dengan kondisi klinis pasien dimana pasien tidak dapat menerima obat yang tercantum di dalam Formularium Nasional dan e-Catalogue. Selain faktor medis tersebut terdapat faktor non medis dari dokter penulis resep maupun terdapat permintaan dari pasien untuk meresepkan obat-obat diluat Formularium Nasional dan e-Catalogue (Pratiwi, 2017).

Penelitian yang dilakukan oleh Febriawati et al (2017) menunjukkan bahwa salah satu penyebab tinginya penulisan resep diluar Formularium Nasional karena dokter penulis resep di Rumah Sakit masih cukup banyak yang meresepkan obat diluar Formularium Nasional. Penulisan resep yang sangat dipengaruhi oleh usaha maketing perusahaan farmasi menyebabkan dokter penulis resep lebih cenderung meresepkan obat diluar Formularium Nasional.

\section{Biaya Rata-rata Obat}

Hasil penelitian menunjukkan total biaya obat yang dikeluarkan oleh Rumah Sakit pada periode Januari-Juni 2018 adalah sebesar Rp 43.868.998,50,-. Biaya tersebut terbilang cukup besar karena dokter menuliskan resep obat-obat diluar Formularium Nasional dan $e$ Catalogue hampir di seluruh resep pasien kardiovaskular, yang dapat dilihat pada Tabel 2.

Tabel 2. Biaya Rata-rata Obat non Formularium Nasional 2017 dan non e-Catalogue 2018 Periode Januari - Juni 2018.

\begin{tabular}{ll}
\hline \multicolumn{1}{c}{ Bulan } & Biaya Obat diluar Formularium Nasional (Rp) \\
\hline Januari & $1.416 .062,50$ \\
Februari & $1.637 .468,00$ \\
Maret & $6.992 .443,00$ \\
April & $12.973 .315,00$ \\
Mei & $12.246 .706,00$ \\
Juni & $8.603 .004,00$ \\
Jumlah Keseluruhan Biaya Obat & $43.868 .998,50$ \\
Biaya Rata-rata Obat/ Bulan & $7.311 .499,75$ \\
Biaya Obat Rata-rata/ Pasien & $217.173,26$ \\
\hline
\end{tabular}

Biaya obat yang tercantum pada Tabel 2 merupakan biaya obat diluar Formularium Nasional dan $e$ - Catalogue. Biaya rata-rata obat diluar Formularium Nasional dan $e$ - 
Catalogue per bulan adalah sebesar Rp 217.173,26,-. Obat yang diresepkan diluar Formularium Nasional dan $e$ - Catalogue merupakan kerugian bagi Rumah Sakit. Hal ini disebabkan karena ketidaksesuaian dengan retriksi yang diberikan oleh BPJS yang mana terdapat selisih antara harga obat yang dibeli dengan obat yang dapat ditagihkan, yang berakibat kegagalan dalam penagihan (klaim) obat ke bagian keuangan dan tim verifikator internal BPJS (Mendrofa, 2016). Selain menimbulkan kerugian bagi Rumah Sakit, peresepan obat diluar Formularium Nasional dan $e$ - Catalogue juga dapat menimbulkan kerugian bagi pasien. Hal ini disebabkan pasien akan dibebankan biaya obat yang diresepkan diluar Formularium Nasional dan $e$ - Catalogue tersebut (Dianingati, 2015).

Masalah yang terjadi sampai saat ini adalah tidak semua jenis obat yang tercantum di Formularium Nasional tersedia di e-Catalogue. Kesulitan dalam pengadaan obat $e$ Catalogue di Rumah Sakit Swasta disebabkan karena belum mendapatkan akses untuk melakukan pembelian melalui system e-Catalogue. Oleh karena itu pembelian obat dilakukan secara offline kepada penyedia di e-Catalogue atau pembelian obat diluar penyedia e-Catalogue (Winda, 2018).

\section{KESIMPULAN}

1. Kesesuaian resep yang ditulis berdasarkan Formularium Nasional dan e-Catalogue adalah sebesar $71,32 \%$.

2. Biaya rata-rata obat yang diresepkan di luar Formularium Nasional dan e-Catalogue per bulan sebesar Rp 7.311.499,75,-, sedangkan biaya rata-rata obat yang dikeluarkan per pasien akibat penggunaan obat non Formularium Nasional dan non e-Catalogue menunjukkan sebesar Rp 217.173,26.--

\section{UCAPAN TERIMAKASIH}

Penulis mengucapkan terimakasih yang sebesar-besarmya kepada Ernawati yang telah membantu dalam penelitian ini.

\section{KONFLIK KEPENTINGAN}

Tidak ada konflik kepentingan 


\section{DAFTAR PUSTAKA}

Aurelia, A., dan Pujiyanto, E. Biaya Satuan dan Pemulihan Biaya (Cost Recovery Rate) Layanan Pasien Acute Coronary Syndrome dengan Rawat Inap di Rumah Sakit X Tahun 2015. Jurnal Kesehatan Masyarakat, 2017; 1 (3): 132-137.

Bhatnagar, P. The Epidemiology of Cardiovascular Disease in the UK 2014. Heart, 2016; (101): 1182-1189.

Dianingati, R.S dan Prasetyo, S.D. Analisis Kesesuaian Resep Untuk Pasien Jaminan Kesehatan Nasional Dengan Indikator Peresepan WHO 1993 Pada Instalasi Farmasi Rawat Jalan Di RSUD Ungaran Periode Januari-Juni 2014. Majalah Farmaseutik, 2015; 11 (3): 362-371.

Hanifa, Z.N. Evaluasi Kesesuaian Peresepan Obat Pada Pasien Umum Rawat Jalan Dengan Formularium RSUI "X” Periode Januari-Maret 2016. Skripsi. Surakarta: Universitas Muhammadiyah Surakarta; 2017.

Khairunnisa, F., Yuniarni, U., Firmansyah, D. Evaluasi Penggunaan Jumlah Obat Non Formularium Nasional pada Pasien BPJS Rawat Jalan di Satu Rumah Sakit Umum Swasta. Seminar Penelitian Sivitas Akademika Unisba; Agustus 2016; Bandung, Indonesia. Indonesia: Universitas Islam Bandung; 2016.

Kemenkes RI. Kepmenkes RI No. HK. 01.07 / MENKES / 659 / 2017 tentang Formularium Nasional. 2017. Available at: https://hukor.kemkes.go.id/ [accessed on: 14 April 2020].

Mendrofa DE dan Suryawati C. Analisis Pengelolaan Obat Pasien BPJS Di Instalasi Farmasi Rumah Sakit Panti Wilasa Citarum Semarang. Jurnal Manajemen Kesehatan Indonesia, 2016; 4(3): 214-221.

Pratiwi WR; Kautsar AP; Gozali D. Hubungan Kesesuaian Penulisan Resep dengan Formularium Nasional Terhadap Mutu Pelayanan pada Pasien Jaminan Kesehatan Nasional di Rumah Sakit Umum di Bandung. Pharm Sci Res, 2017; 4(1): 48-56.

Pusat Data dan Informasi Kementrian Kesehatan RI. Info Datin Situasi Kesehatan Jantung 2014. Available at: https://pusdatin.kemkes.go.id/ [accessed on 14 April 2020].

Taroreh GN; Mpila D; Citraningtyas G. Evaluasi Penggunaan Obat Pada Pasien Dengan Penyakit Jantung Koroner Di Instalasi Rawat Inap RSUP Prof. Dr. R. D. Kandou Manado. Pharmaacon, 2017; 6(4): 55-66.

Winda S. Formularium Nasional dan e-Catalogue Obat Sebagai Upaya Pencegahan Korupsi dalam Tata Kelola Obat Jaminan Kesehatan Nasional (JKN). Integritas, 2018; 4(2): 181-202. 